\title{
シンポジウム $1-6$
}

\section{クリニカルクエスチョン (CQ) その2：運動後急性腎障害に対する キサンチンオキシドレダクターゼ阻害薬の使用}

太田原 顕

強度の高い運動 (無酸素運動)により背部痛を 伴ったクレアチンキナーゼやミオグロビンの上 昇を認めない急性腎障害 (運動後急性腎障害) が時に経験されるが,この運動後急性腎障害 (Exercise-induced acute kidney injury: EIAKI) は, 運動性横紋筋融解により生じるミオグロビン尿を 伴った急性腎障害とは異なった病態と考えられて いる。 そしてEIAKIは腎性低尿酸血症 (RHUC) 患 者に認められることが多いとされている.

EIAKI予防のため, 運動前にキサンチンオキシ ドレダクターゼ (XOR) 阻害薬を投与することが 提唱されているが，これまでその有効性につい ては不明であった。そこで，CQとして，「RHUC 患者において, EIAKIの予防のために, 薬物療法 としてXOR 阻害薬は投与されるべきか? 」が設 定された. システマティック・レビューにおい て, 1 次スクリーニングにより 54 文献が収集され, うち 2 次スクリーニングで 43 文献が抽出された. EIAKIは突発的に起こる腎障害であり，症例数を 収集した介入試験などの実施が困難である。これ までの報告も数例の介入試験報告あるいは症例報 告をまとめたレビューに留まっており，十分なエ ビデンスレベルを持った文献は存在しなかった。

EIAKIの発症機序には不明な点が多いが，近年 の画像診断により虚血性変化が関与している可能 性が示唆されている。長期予後は不明であるが多 くの症例が一過性の腎障害を生じるものの維持透 析に移行した報告はない.しかしながら透析療 法が一時的に必要とされる症例や可逆性後頭葉
白質脳症 (PRES) といわれる急性期に神経症状を 伴った脳浮腫を呈する症候群が生じる報告もあっ た，RHUCでの再発例の報告もあり，アスリート のEIAKI報告もある一方で，同じアスリートの腎 性低尿酸血症でも EIAKIを生じないという報告も あった。

発症機序の仮説に基づく予防策として，XOR 阻害薬であるアロプリノールを投与された報告は あるが,それらのエビデンスは十分とはいえない. アロプリノールがEIAKIを抑制する可能性に言及 した記載はあるものの，日本ならびに東アジアに おける検討や介入研究, 多数症例での報告はいず れもなく，投与量や投与期間に関しても論拠とな る報告はみられなかった。

以上の議論から，CQへの結論を「EIAKI予防 のために，薬物療法としてXOR阻害薬を投与す るべきかどうかは明確には推奨できない」とした。 ただし，XOR阻害薬によりEIAKIの発症や再発 を予防できる可能性があることから，「特に運動 後急性腎障害のリスクを持つ患者 (既往のある患 者や運動選手など）に対しては益と害を十分に勘 案し, 適応を決めるべきである」という推奨も提 示された。この重要臨床課題については, 今後の 研究のさらなる進展がま待たれる。 